\title{
A Highly Selective Turn-On Fluorescent Probe for the Detection of Zinc
}

\author{
Ling-Yi Shen ${ }^{1,2,+}$, Xiao-Li Chen ${ }^{2,+}$, Xian-Jiong Yang ${ }^{1,2, *}$, Hong $\mathrm{Xu}^{2}{ }^{2}$, Ya-Li Huang ${ }^{2}$, Xing Zhang ${ }^{2}$, \\ Carl Redshaw ${ }^{3}$ and Qi-Long Zhang ${ }^{1,2, *}$
}

1 The Key Laboratory of Environmental Pollution Monitoring and Disease Control, School of Public Health, Ministry of Education, Guizhou Medical University, Guiyang 550014, China; shenly@stumail.nwu.edu.cn

2 School of Basic Medical Science, Guizhou Medical University, Guiyang 550004, China; C13885297112@163.com (X.-L.C.); xuhong@gmc.edu.cn (H.X.); ylh6401@gmc.edu.cn (Y.-L.H.); zhangxing11207115@126.com (X.Z.)

3 Department of Chemistry, University of Hull, Cottingham Road, Hull, Yorkshire HU6 7RX, UK; c.redshaw@hull.ac.uk

* Correspondence: yangxianjiong@gmc.edu.cn (X.-J.Y.); sciqlzhang@gmc.edu.cn (Q.-L.Z.); Fax: +86-0851-88174017 (Q.-L.Z.)

+ These authors contributed equally to this work.

Citation: Shen, L.-Y.; Chen, X.-L.; Yang, X.-J.; Xu, H.; Huang, Y.-L.; Zhang, X.; Redshaw, C.; Zhang, Q.-L. A Highly Selective Turn-On Fluorescent Probe for the Detection of Zinc. Molecules 2021, 26, 3825. https://doi.org/10.3390/ molecules26133825

Academic Editor: Mikhail A. Kiskin

Received: 23 May 2021

Accepted: 19 June 2021

Published: 23 June 2021

Publisher's Note: MDPI stays neutral with regard to jurisdictional claims in published maps and institutional affiliations.

Copyright: (c) 2021 by the authors. Licensee MDPI, Basel, Switzerland. This article is an open access article distributed under the terms and conditions of the Creative Commons Attribution (CC BY) license (https:/ / creativecommons.org/licenses/by/ $4.0 /)$.

\begin{abstract}
A novel turn-on fluorescence probe $\mathbf{L}$ has been designed that exhibits high selectivity and sensitivity with a detection limit of $9.53 \times 10^{-8} \mathrm{~mol} / \mathrm{L}$ for the quantification of $\mathrm{Zn}^{2+} \cdot{ }^{1} \mathrm{H}-\mathrm{NMR}$ spectroscopy and single crystal $\mathrm{X}$-ray diffraction analysis revealed the unsymmetrical nature of the structure of the Schiff base probe L. An emission titration experiment in the presence of different molar fractions of $\mathrm{Zn}^{2+}$ was used to perform a Job's plot analysis. The results showed that the stoichiometric ratio of the complex formed by $\mathbf{L}$ and $\mathrm{Zn}^{2+}$ was 1:1. Moreover, the molecular structure of the mononuclear $\mathrm{Cu}$ complex reveals one ligand $\mathrm{L}$ coordinates with one $\mathrm{Cu}$ atom in the asymmetric unit. On adding $\mathrm{CuCl}_{2}$ to the $\mathrm{ZnCl}_{2} / \mathrm{L}$ system, a Cu-Zn complex was formed and a strong quenching behavior was observed, which inferred that the $\mathrm{Cu}^{2+}$ displaced $\mathrm{Zn}^{2+}$ to coordinate with the imine nitrogen atoms and hydroxyl oxygen atoms of probe $\mathbf{L}$.
\end{abstract}

Keywords: fluorescent probe; Schiff base; crystal structure; titration experiments

\section{Introduction}

Zinc is the second most abundant transition metal ion in the human body and is essential for various biochemical processes, such as neurotransmission, enzyme regulation, gene expression, and apoptosis [1-4]. In addition, zinc at normal concentrations controls many metabolic, biological, and environmental processes, while deficiency usually leads to the appearance of some clinical diseases, such as growth retardation, brain dysfunction, high blood cholesterol, Parkinson's disease, ischemic stroke, Alzheimer's disease, etc. [5-9]. On the other hand, excessive zinc will also cause problems for humans; for example, it will reduce soil microbial activity and cause phytotoxic effects [10-14]. Therefore, it is of great significance to be able to accurately detect zinc ion concentration [15-18].

At present, the main detection methods of zinc include spectrophotometry, electrochemical methods [19], atomic absorption methods [20], chromatographic methods, and mass spectrometry [21,22]. However, due to the high cost of equipment, cumbersome sample preparation, or prolonged testing time, the wide application of these methods in actual testing has been limited. Among various detection methods, metal ion fluorescent chemical sensors have attracted much attention because of the convenient use, high sensitivity, and ability to directly measure concentration through fluorescent signals [23-27]. $\mathrm{Zn}^{2+}$ fluorescent probes can be divided into three categories: fluorescence quenching, fluorescence enhanced type, and ratio type. There is still an urgent need to develop new 
small molecule probes that are easy to prepare, have high sensitivity, and can recognize $\mathrm{Zn}^{2+}$ with excellent selectivity.

Schiff bases can coordinate with a variety of metals due to their special chemical structure, so they are considered to be dominant ligands for metal ions [28]. Schiff bases and their transition metal complexes not only have a wide range of applications in synthesis, catalytic chemistry, and materials chemistry [29], but also have a wide range of applications in antibacterial, antifungal, anticancer [30], clinical, analytical, and pharmacological aspects [31-34]. Moreover, a series of Schiff base ligands have been reported to be fluorescence turn-on chemosensors for $\mathrm{Zn}^{2+}$ with high sensitivity and selectivity [35-40]. Such systems are based on several reported mechanisms of fluorescence enhancement behavior, including internal charge transfer (ICT) [41], chelating-enhanced fluorescence (CHEF) [42,43], photoinduced electron transfer (PET) [44,45], aggregation-induced emission (AIE) [46-48], and $\mathrm{C}=\mathrm{N}$ isomerization mechanisms [49-51]. In the current work, we have designed an asymmetric Schiff base $\mathbf{L}$ that not only has the ability to chelate metals but also has lone pair electrons on nitrogen atoms. The synthesis of $\mathbf{L}$ is shown in Scheme 1 , and its structure has been confirmed by NMR spectroscopy, mass spectrometry, single crystal X-ray diffraction, and UV-Vis spectroscopy.

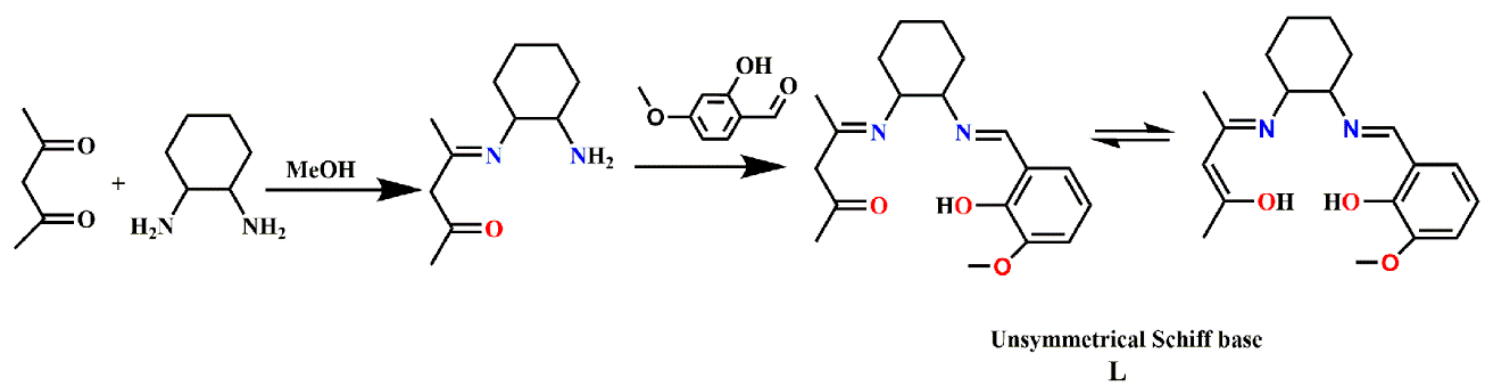

Scheme 1. Synthesis of Schiff base compound L.

The fluorescence spectrum indicated little fluorescence emission of the free probe $\mathbf{L}$. However, after adding $\mathrm{Zn}^{2+}$, $\mathrm{L}$ exhibited a fluorescence emission peak at $475 \mathrm{~nm}$ and a 512-fold fluorescence enhancement. Meanwhile, qualitative and quantitative detection are achieved through the linear relationship between fluorescence intensity and zinc ion concentration. Additionally, most of the coexisting metal ions had little or negligible interference on the emission response of probe $\mathbf{L}$ toward $\mathrm{Zn}^{2+}$. Of particular note is $\mathrm{Cd}^{2+}$, which has very similar chemical properties to $\mathrm{Zn}^{2+}$, and most $\mathrm{Zn}^{2+}$ sensors tend to respond to both $\mathrm{Zn}^{2+}$ and $\mathrm{Cd}^{2+}$ [32-35]. Hence, the development of a $\mathrm{Zn}^{2+}$ selective fluorescence sensor that can discriminate $\mathrm{Zn}^{2+}$ from $\mathrm{Cd}^{2+}$ is a great challenge and is of great significance. The recognition mechanism of the probe for $\mathrm{Zn}^{2+}$ in ethanol solution is proposed to be $\mathrm{C}=\mathrm{N}$ isomerization [49-51] and chelation-enhanced fluorescence [42,43]. The $\mathrm{C}=\mathrm{N}$ isomerization is inhibited by the coordination of $\mathrm{Zn}^{2+}$ with the probe $\mathbf{L}$, so the fluorescence is significantly enhanced. Moreover, both $\mathrm{Zn}^{2+}$ and $\mathrm{Cu}^{2+}$ were investigated as the metal ions to coordinate simultaneously with $\mathbf{L}$ in order to understand the strong quenching behavior of $\mathrm{Cu}^{2+}$.

\section{Results and Discussion}

\subsection{Selectivity of the Probe $\mathbf{L}$}

To determine potential practical applications, the spectroscopic properties of $\mathbf{L}$ were measured under simulated physiological conditions ( $50 \mu \mathrm{M}$ in ethanol solution). The probe will be deactivated when the water content exceeds $5 \%$, and thus the fluorescence spectral response of $\mathbf{L}$ to metal ions was recorded in ethanol solution excited at $354 \mathrm{~nm}$ as shown in Figure 1. The fluorescence spectroscopic response of $\mathbf{L}$ toward metal ions was evaluated in ethanol solution upon excitation at $354 \mathrm{~nm}$ as presented in Figure 1. The fluorescence spectroscopy indicated that the addition of $\mathrm{Zn}^{2+}$ resulted in a significant enhancement of the emission intensity positioned at $475 \mathrm{~nm}$ (Figure 1A, blue line). Under the same 
conditions, next to no responsive changes are observed in the presence of 1 equiv. of various metal cations (solutions of $\mathrm{Zn}^{2+}, \mathrm{Li}^{+}, \mathrm{Na}^{+}, \mathrm{K}^{+}, \mathrm{Ag}^{+}, \mathrm{Mg}^{2+}, \mathrm{Ca}^{2+}, \mathrm{Sr}^{2+}, \mathrm{Ba}^{2+}, \mathrm{Al}^{3+}$, $\mathrm{Fe}^{3+}, \mathrm{Co}^{2+}, \mathrm{Ni}^{2+}, \mathrm{Cu}^{2+}, \mathrm{Pb}^{2+}, \mathrm{Cd}^{2+}$, and $\mathrm{Hg}^{2+}$ were prepared from their chloride salts) in ethanol. Thus, according to the spectroscopy changes, the Schiff base probe $\mathbf{L}$ can detect $\mathrm{Zn}^{2+}$ with good selectivity.
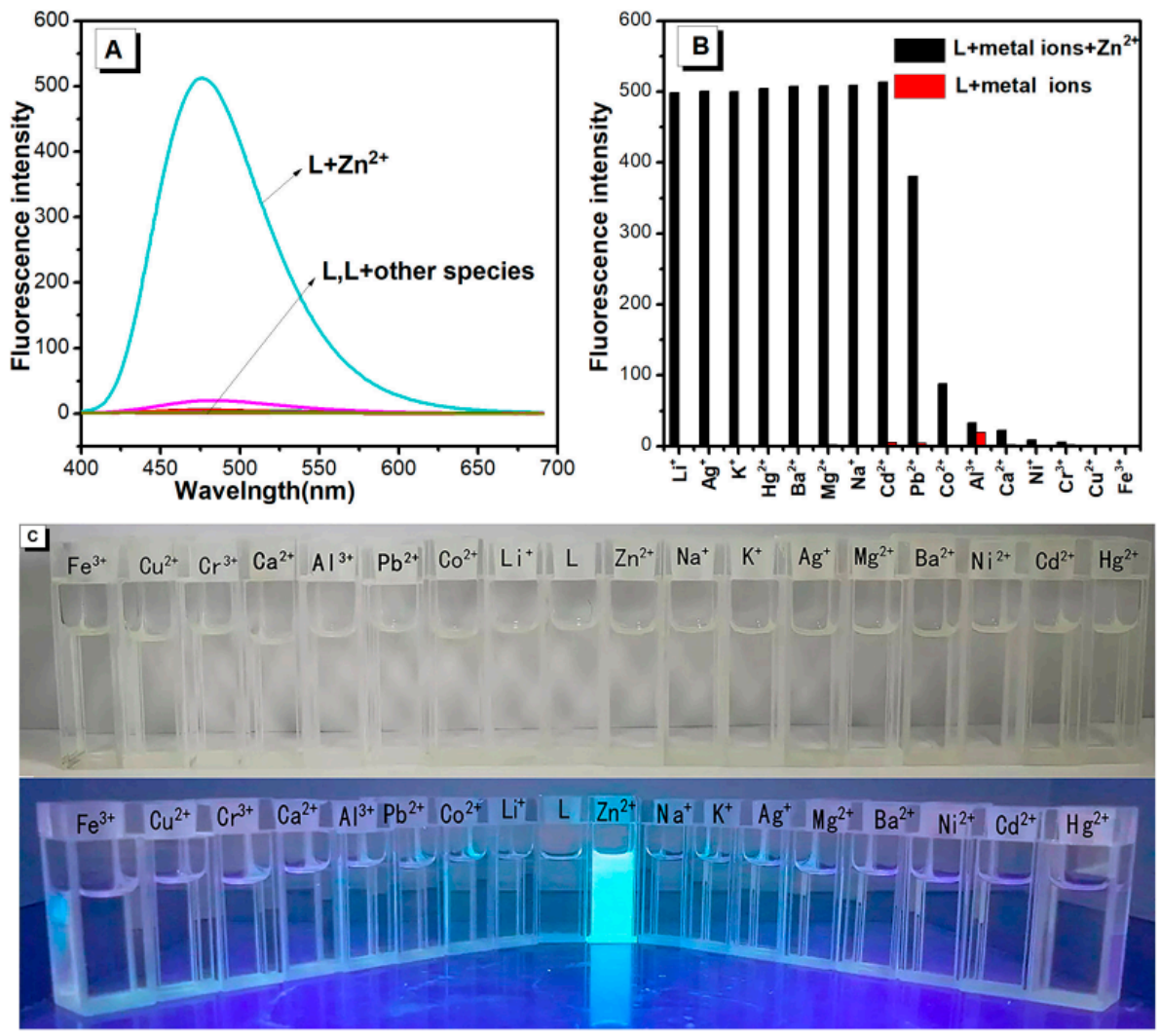

Figure 1. (A) Fluorescence spectra of $\mathbf{L}(50 \mu \mathrm{mol} / \mathrm{L})$ and upon the addition of salts (1 equiv.) of $\mathrm{Li}^{+}$, $\mathrm{Na}^{+}, \mathrm{K}^{+}, \mathrm{Ag}^{+}, \mathrm{Mg}^{2+}, \mathrm{Ca}^{2+}, \mathrm{Ba}^{2+}, \mathrm{Al}^{3+}, \mathrm{Fe}^{3+}, \mathrm{Co}^{2+}, \mathrm{Ni}^{2+}, \mathrm{Cu}^{2+}, \mathrm{Zn}^{2+}, \mathrm{Pb}^{2+}, \mathrm{Cd}^{2+}, \mathrm{Hg}^{2+}$, and $\mathrm{Cr}^{3+}$ in $\mathrm{CH}_{3} \mathrm{CH}_{2} \mathrm{OH}$. (B) Black bar: Relative fluorescence of $\mathbf{L}$ with 1 equiv. of metal ions stated; Red bar: Relative fluorescence of $\mathbf{L}$ and 1 equiv. of $\mathrm{Zn}^{2+}$ with 1 equiv. of metal ions stated $\left(E_{\mathrm{ex}}=354 \mathrm{~nm}\right.$, $E_{\mathrm{em}}=475 \mathrm{~nm}$ ). (C) Photos of $\mathrm{L}$ responding to $17 \mathrm{kinds}$ of other metal ions and $\mathrm{Zn}^{2+}$ under visible light (above) and UV light (below).

\subsection{Competition Experiments}

It is necessary for a metal ion fluorescence chemosensor to achieve higher selectivity over other competing metal ions. Therefore, we evaluated the fluorescence behavior of probe $\mathbf{L}$ for $\mathrm{Zn}^{2+}$ in the presence of various competing metal ions, in which $\mathbf{L}$ was treated with 1 equiv. of $\mathrm{Zn}^{2+}$ in the presence of 1 equiv. of other metal ions. Figure $1 \mathrm{~B}$ summarizes the results, and reveals that the presence of $\mathrm{Li}^{+}, \mathrm{Na}^{+}, \mathrm{K}^{+}, \mathrm{Ag}^{+}, \mathrm{Hg}^{2+}, \mathrm{Mg}^{2+}, \mathrm{Hg}^{2+}, \mathrm{Ba}^{2+}$, and $\mathrm{Pb}^{2+}$ caused only minor interference for the detection of $\mathrm{Zn}^{2+}$, whilst the presence of $\mathrm{Co}^{2+}$, $\mathrm{Al}^{3+}, \mathrm{Ca}^{2+}, \mathrm{Ni}^{2+}$, and $\mathrm{Cr}^{3+}$ resulted in low fluorescence intensity but were clearly detectable. However, in the case of $\mathrm{Fe}^{3+}$ and $\mathrm{Cu}^{2+}$, quenching of the fluorescence signal was observed, which may be due to the paramagnetic nature of $\mathrm{Cu}$ (II) and $\mathrm{Fe}(\mathrm{III})$ and their stronger coordinating ability than $\mathrm{Zn}(\mathrm{II})$. The fluorescence probe for detecting $\mathrm{Zn}^{2+}$ in the presence of coexisting metal ions, except for $\mathrm{Fe}^{3+}$ and $\mathrm{Cu}^{2+}$, clearly maintains higher emission than observed for the free probe $\mathbf{L}$. Moreover, $\mathrm{Cd}^{2+}$ did not inhibit the emission intensity of $\mathrm{Zn}^{2+}$. Thus, these results indicate that probe $\mathbf{L}$ could be used as a selective probe for $\mathrm{Zn}^{2+}$ for distinguishing $\mathrm{Zn}^{2+}$ from $\mathrm{Cd}^{2+}$, which commonly share similar properties. 


\subsection{Fluorescence Spectroscopic Studies of $\mathbf{L}$ toward $\mathrm{Zn}^{2+}$}

The result of the fluorometric titration of the free probe $\mathbf{L}$ and those in the presence of incremental amounts of $\mathrm{Zn}^{2+}$ in ethanol solution is shown in Figure 2A. The fluorescence spectrum showed that the fluorescence intensity increases steadily and smoothly on increasing the $\mathrm{Zn}^{2+}$ concentration. On addition of up to 1 equiv. of $\mathrm{Zn}^{2+}$, the turn-on ratio was observed to increase by over 512-fold. Additionally, the dependence of the emission intensity at $475 \mathrm{~nm}$ on the $\mathrm{Zn}^{2+}$ concentration is shown in Figure 2B. The fluorescence intensity remained constant in the presence of more than 1 equiv. of $\mathrm{Zn}^{2+}$, and therefore, the formation of a 1:1 complex between $\mathbf{L}$ and the $\mathrm{Zn}^{2+}$ was proposed. According to the fluorescence titration data, the association constant for $\mathbf{L}-\mathrm{Zn}^{2+}$ complexation was calculated at $1.42 \times 10^{4} \mathrm{~mol} / \mathrm{L}$ from the Benesi-Hildebrand plot (Figure $2 \mathrm{C}$ ). For practical purposes, the detection limit of probe $\mathrm{L}$ is an important parameter. The detection limit of probe $\mathbf{L}$ for $\mathrm{Zn}^{2+}$ was determined to be $9.53 \times 10^{-8} \mathrm{~mol} / \mathrm{L}$ according to the IUPAC definition $(\mathrm{CDL}=3 \mathrm{Sb} / \mathrm{m})$ from 10 blank solutions [52,53]. The Job's plot analysis shows that a maximum emission was observed when the molar fraction reached 0.5, suggesting that the complex formation between $\mathbf{L}$ and $\mathrm{Zn}^{2+}$ has the stoichiometric ratio of 1:1. A linear relationship $\left(R^{2}=0.99173\right)$ for the plot of the normalized fluorescence intensity at $475 \mathrm{~nm}$ against $\mathrm{Zn}^{2+} / \mathrm{L}$ is shown in Figure 2D.
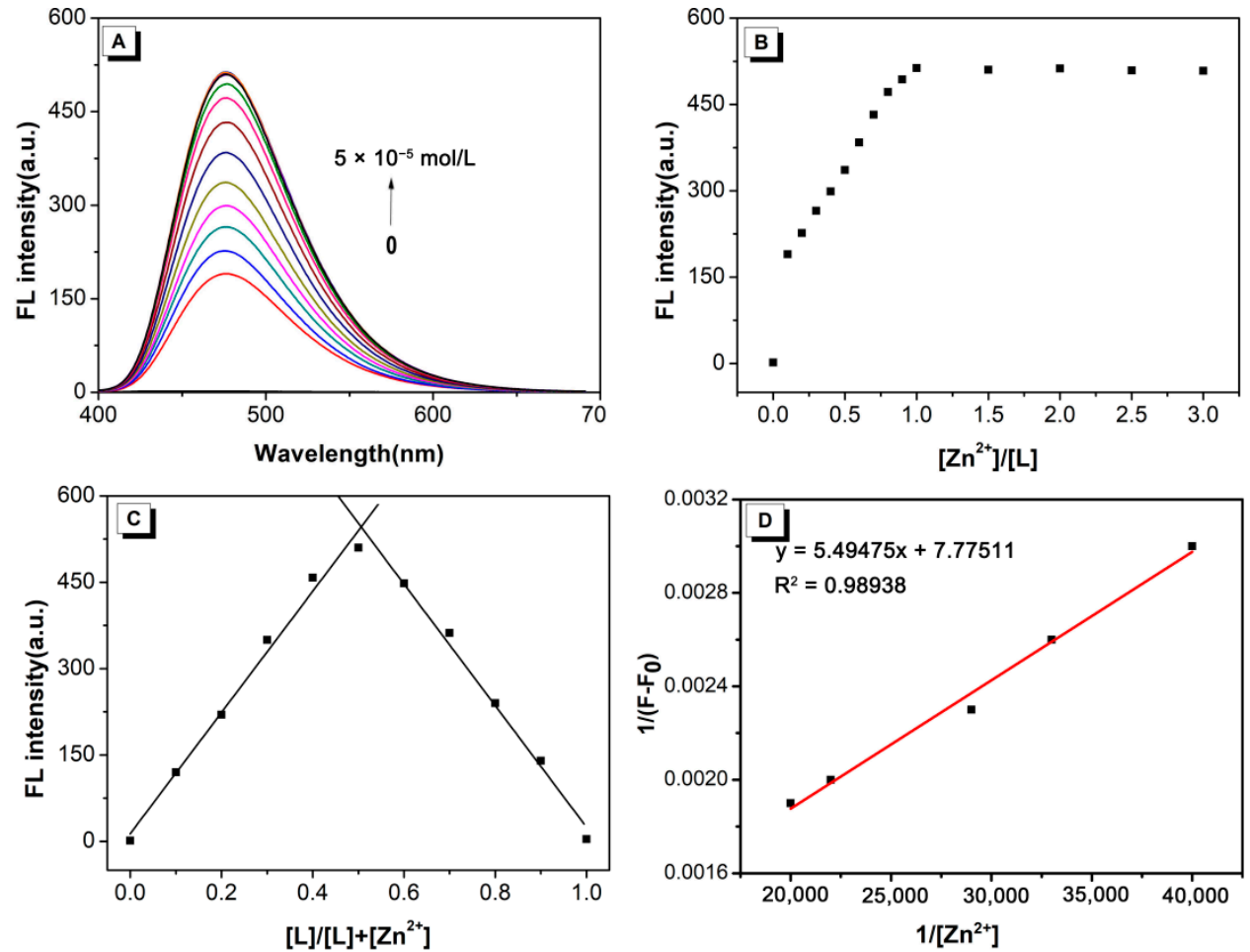

Figure 2. (A) Fluorescent titration spectra of $\mathbf{L}(50 \mu \mathrm{mol} / \mathrm{L})$ in the presence of different concentrations of $\mathrm{ZnCl}_{2}$. (B) The fluorescence at $475 \mathrm{~nm}$ of $\mathrm{L}$ as a function of the $\mathrm{Zn}^{2+}$ concentration. (C) Job's plot for the determination of the stoichiometry of $\mathbf{L}$ and $\mathrm{Zn}^{2+}$ in ethanol, the total concentration of $\mathbf{L}$ and $\mathrm{Zn}^{2+}$ was $50 \mu \mathrm{M}$. (D) The Benesi-Hildebrand plot of $1 /$ (F - F0) versus $1 /\left[\mathrm{Zn}^{2+}\right]$.

For a rough comparison between present complex with other reported similar fluorescent sensors [35,37-39,54,55], based on the detection limits of fluorescent sensors for $\mathrm{Zn}^{2+}$, see the results gathered in Table 1 . The present compound is clearly more sensitive than most of the other Schiff base fluorescent sensors for the detection of $\mathrm{Zn}^{2+}$ via turn-on fluorescence. 
Table 1. Comparison of various fluorescent sensors for $\mathrm{Zn}^{2+}$.

\begin{tabular}{|c|c|c|c|}
\hline Compound & Solvent & Detection Limit & Ref. \\
\hline & $\mathrm{CH}_{3} \mathrm{OH} / \mathrm{H}_{2} \mathrm{O}$ & $2.84 \times 10^{-7} \mathrm{M}$ & 54 \\
\hline & $\mathrm{CH}_{3} \mathrm{OH}$ & $7.74 \times 10^{-7} \mathrm{M}$ & 38 \\
\hline & $\mathrm{CH}_{3} \mathrm{OH} / \mathrm{H}_{2} \mathrm{O}$ & $4.80 \times 10^{-7} \mathrm{M}$ & 37 \\
\hline & $\mathrm{CH}_{3} \mathrm{OH}$ & $7.69 \times 10^{-9} \mathrm{M}$ & 55 \\
\hline & EtOH/HEPES buffer & $5.03 \times 10^{-7} \mathrm{M}$ & 39 \\
\hline & DMSO/water & $\sim 1.00 \times 10^{-8} \mathrm{M}$ & 35 \\
\hline & $\mathrm{EtOH}$ & $9.53 \times 10^{-8} \mathrm{M}$ & Present work \\
\hline
\end{tabular}

\subsection{UV-Vis Absorbance Response of Probe $\mathbf{L}$ towards $\mathrm{Zn}^{2+}$}

As illustrated in Figure 3, the probe $\mathbf{L}$ exhibited a maximal absorption at $313 \mathrm{~nm}$. Upon addition of $\mathrm{Zn}^{2+}$ ions ( $0-1$ equiv.), the absorbance at $313 \mathrm{~nm}$ decreased gradually on gradually increasing the $\mathrm{Zn}^{2+}$ concentration (Figure S4, Supplementary Materials). The presence of two clear isosbestic points at $273,339 \mathrm{~nm}$ is consistent with the conversion of the free probe $\mathbf{L}$ to the $\mathrm{Zn}^{2+}$ complex. Moreover, the absorbance at $313 \mathrm{~nm}$ hardly changes in the presence of more than 1 equiv. of $\mathrm{Zn}^{2+}$ ions, indicating the formation of a 1:1 complex between $\mathbf{L}$ and the zinc ion. This is in good agreement with a 1:1 stoichiometry for the $\mathrm{Zn}^{2+}$ complex as determined by the Job's plot obtained from UV-Vis absorption (Figure S5, Supplementary Materials). 


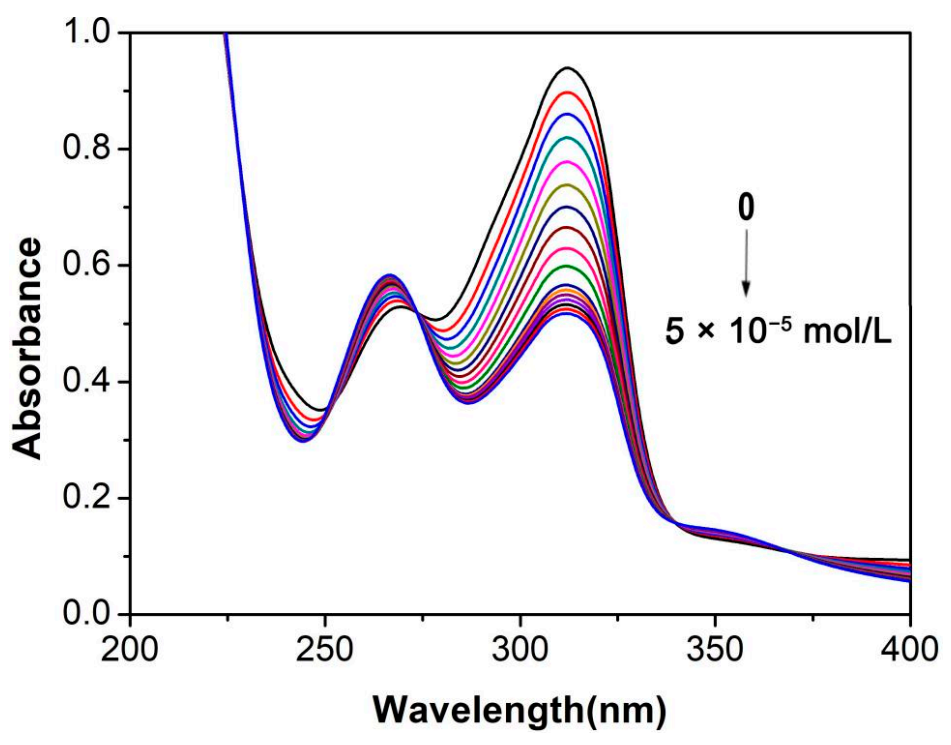

Figure 3. UV-Vis spectra of $\mathbf{L}(50 \mu \mathrm{mol} / \mathrm{L})$ with increasing amounts of $\mathrm{ZnCl}_{2}$ (0-3 equiv.).

\subsection{Crystal Structures of Probe $\mathbf{L}$ and Metal Complexes}

To further investigate the binding mode of $\mathbf{L}$ with other metal ions, probe $\mathbf{L}$ and the organic framework of $\mathbf{L}$ possess an approximate torsional structure which chelates with one equivalent of $\mathrm{Cu}^{2+}$ ions. Moreover, a heteronuclear bimetallic complex was also obtained. The geometrical parameters of the mononuclear $\mathrm{Cu}$ complex, $\mathrm{Cu}-\mathrm{Zn}$ complex, and $\mathbf{L}$ are listed in Table S1, Supplementary Materials. Treatment of 2,4-pentanedione with $(1 R, 2 R)$-diaminocyclohexane in refluxing methanol for $15 \mathrm{~min}$, cooling, followed by the addition of 2-hydroxy-3-methoxybenzaldehyde led to the target product $\mathbf{L}$, which was obtained from the filtrate on standing overnight below $0{ }^{\circ} \mathrm{C}$. The reaction generally affords a high yield $(84 \%)$, and yellow crystals suitable for X-ray determination were obtained (Figure $4 a$ ). The probe $\mathbf{L}$ is found to be unsymmetrical as shown by the crystal structure and the potential coordination sites in the two side chains point in opposite directions. Additionally, the bond lengths of N1-C17 and N2-C7 are 1.319(10) A and 1.310(12) $\AA$, respectively, corresponding to a $\mathrm{C}=\mathrm{N}$ double bond. Both bond lengths of

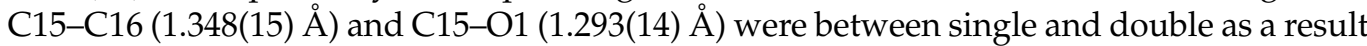
of contributing to the conjugation effect. Moreover, all the atoms (except for hydrogen) in each side chain are coplanar and the dihedral angle of the two planes is $61.28^{\circ}$, thereby making the whole molecule appear " $\mathrm{V}$ " shaped.
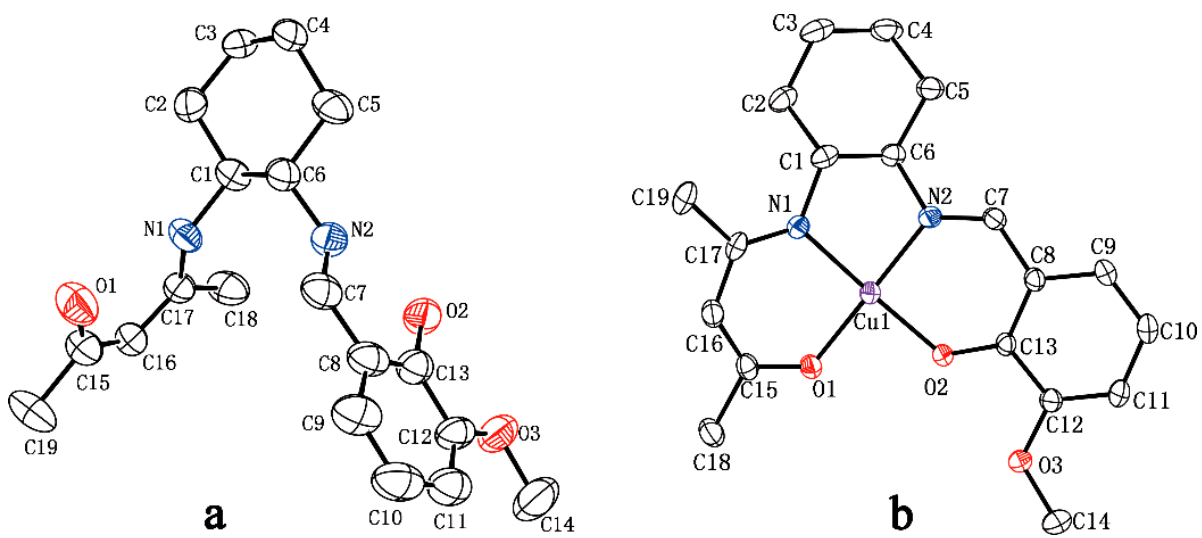

Figure 4. (a) X-ray crystal structure of probe L; (b) X-ray crystal structure of Cu-complex. Thermal ellipsoids are set at the $30 \%$ probability level and all hydrogen atoms and solvent molecules were omitted for clarity. 
To synthesize the copper complex, ligand $\mathbf{L}$ was treated with an equivalent of $\mathrm{CuCl}_{2}$ at room temperature, and following work-up, brown crystals were afforded. X-ray crystallographic analysis (Figure $4 \mathrm{~b}$ ) shows that the $\mathrm{Cu}^{2+}$ complex is a mononuclear complex, where the asymmetric unit consists of one ligand $\mathbf{L}$ and one $\mathrm{Cu}$ atom, giving rise to a 1:1 ligand to metal coordination. The central $\mathrm{Cu}^{2+}$ is four-coordinate with one phenoxide oxygen atom, and one enolic hydroxyl oxygen atom and two imine nitrogen atoms. Moreover, the four-coordinated atoms are almost coplanar, in which the dihedral angle of N1-Cu1-O1 and N2-Cu2-O2 is only $9.21^{\circ}$. The bond lengths of N1-C17 and N2-C7 are 1.309(5) $\AA$ and $1.290(5) \AA$, respectively, and are shorter than in the neutral ligand. The bond lengths to $\mathrm{Cu}$ are comparable with corresponding values observed in similar complexes $[56,57]$. The $\mathrm{Cu}$ complex clearly shows quenched fluorescence, which might be due to the $\mathrm{d}^{9}$ electron configuration of the $\mathrm{Cu}^{2+}$ ions making the transfer of ligand electrons from the excited states to the d-orbital of $\mathrm{Cu}^{2+}$ rather than transferring back to the ground state of the ligand [58].

In order to understand the strong quenching behavior when coexisting $\mathrm{Cu}^{2+}$ and $\mathrm{Zn}^{2+}$ are present, we added $\mathrm{CuCl}_{2}$ to the solution of $\mathrm{ZnCl}_{2} / \mathrm{L}$. As expected, the solution shows an obvious quenched fluorescence. Moreover, a heteronuclear bimetallic complex was obtained by concentrating the solution. The solid-state molecular structure is shown in Figure 5, as determined by X-ray crystallography. This revealed that the asymmetric unit is composed of two fragments that are connected by two bridged chlorine atoms to construct a dimeric heteronuclear metal complex. The coordination environment of the copper atom is a slightly distorted square-planar involving two $\mathrm{O}$ and $\mathrm{N}$ atoms from the $\mathbf{L}^{2-}$ ligand, which is similar to that in the above-mentioned mononuclear $\mathrm{Cu}$-complex. Moreover, the zinc has a distorted tetrahedral environment, in which the zinc atom is coordinated by the two $\mathrm{O}$ atoms of the $\mathrm{L}^{2-}$ ligand and the two $\mathrm{Cl}$ atoms. The average angle of $\mathrm{Cl}-\mathrm{Zn}-\mathrm{Cl}$ is $116.96(11)$ and the $\mathrm{Cl}-\mathrm{Zn}-\mathrm{Cl}$ planes are nearly perpendicular to the $\mathrm{CuL}$ units, respectively, which decreases the steric effects between them. The distances between $\mathrm{Cu}$ and $\mathrm{Zn}$ are $3.106 \AA$ and $3.101 \AA$ in each half of the molecule, respectively. The core feature of the bimetallic structure possesses an average $\mathrm{Cu}-\mathrm{O}$ bond of $1.919 \AA$ and $\mathrm{Zn}-\mathrm{O}$ bond of $2.146 \AA$, accompanied by an average $\mathrm{Zn}-\mathrm{Cl}$ bond of $2.220 \AA$ and $\mathrm{Cu}-\mathrm{N}$ bond of $1.939 \AA$. These values are comparable with corresponding values observed in similar $\mathrm{Cu}-\mathrm{Zn}$ complexes $[59,60]$. The formation of the $\mathrm{Cu}-\mathrm{Zn}$ complex indicates that the $\mathrm{Cu}^{2+}$ can displace the $\mathrm{Zn}^{2+}$ to coordinate with the imine nitrogen atoms and the hydroxyl oxygen atoms of probe $\mathrm{L}$. In this regard, the formation of complex $\mathrm{Cu}-\mathrm{Zn}$ would be the main cause of the strong quenching behavior when $\mathrm{Cu}^{2+}$ coexists in the presence of $\mathrm{Zn}^{2+} / \mathrm{L}$.
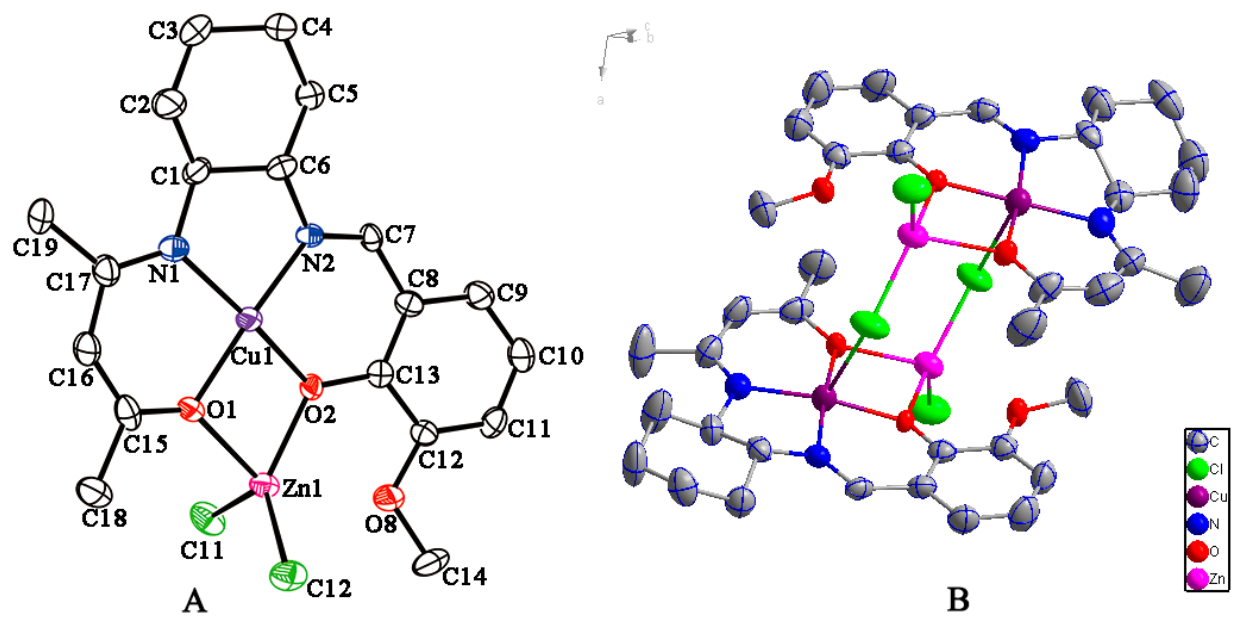

Figure 5. (A) X-ray crystal structure of the $\mathrm{Cu}-\mathrm{Zn}$ complex (thermal ellipsoids are set at the $30 \%$ probability level); (B) ball-and-stick views of the dimer. All hydrogen atoms and solvent molecules were omitted for clarity. 


\subsection{Proposed Recognition Mechanism}

To better understand the recognition mechanism in the detection of $\mathbf{L}$ for $\mathrm{Zn}^{2+}$, the ${ }^{1} \mathrm{H}$ NMR spectroscopic titration experiment was performed as shown in Figure S6, Supplementary Materials. It shows that the proton peaks at $\delta=13.49$ and $10.74 \mathrm{ppm}$ of the phenolic hydroxyl and enol hydroxyl, respectively, of probe $\mathbf{L}$ gradually decreased on the addition of zinc ions. Especially, the proton peak of the phenolic hydroxyl was almost completely gone when the addition of $\mathrm{Zn}^{2+}$ reached 1.0 equivalent, which indicated that the $\mathrm{Zn}^{2+}$ coordinates to the two $\mathrm{O}$ atoms with the stoichiometric ratio 1:1. The enol hydroxyl proton peak remains because the enol and ketone can still interchange. On the other hand, based on the Job's plot analysis and the structures of similar types of zinc complexes reported in the literature [61-63], we propose the structure of a 1:1 complex for $\mathbf{L}$ and $\mathrm{Zn}^{2+}$ is as shown in Scheme 2. The remarkable increase of the fluorescence of probe $\mathbf{L}$ at $475 \mathrm{~nm}$ can be explained as follows: the probe $\mathbf{L}$ with a $\mathrm{C}=\mathrm{N}$ containing structure shows little fluorescence because of $\mathrm{C}=\mathrm{N}$ isomerization, which leads to the predominant decay in the excited states [64]. In contrast, the nitrogen containing lone pair electrons coordinate with the zinc ions and form a bond to restrain the $\mathrm{C}=\mathrm{N}$ isomerization so that its fluorescence increases drastically [65]. Moreover, the complexation of $\mathrm{Zn}^{2+}$ with $\mathbf{L}$ leads to a more rigid molecule, and produces a large chelation-enhanced fluorescence detection effect, which leads to a large increase in the fluorescence [66]. On the other hand, it has been reported that transition metal cations with closed shell d-orbitals cannot form low-energy metal center excited states or charge-separated excited states to provide the obvious fluorescence enhancement. However, transition metal cations with open shell d-orbitals usually quench fluorescence due to electron or energy transfer between the metal cation and the fluorophore, providing rapid and effective non-radiative decay of the excited state [67]. The formation of $\mathrm{Cu}-\mathrm{Zn}$ complex implies that $\mathrm{Cu}^{2+}$ with its open shell d-orbitals replaces $\mathrm{Zn}^{2+}$ with closed shell $\mathrm{d}$-orbitals and coordinates with $\mathrm{C}=\mathrm{N}$ bond of the ligand. Hence, strong quenching of the fluorescence was observed following the addition of $\mathrm{CuCl}_{2}$ to the $\mathrm{ZnCl}_{2} / \mathrm{L}$ system.

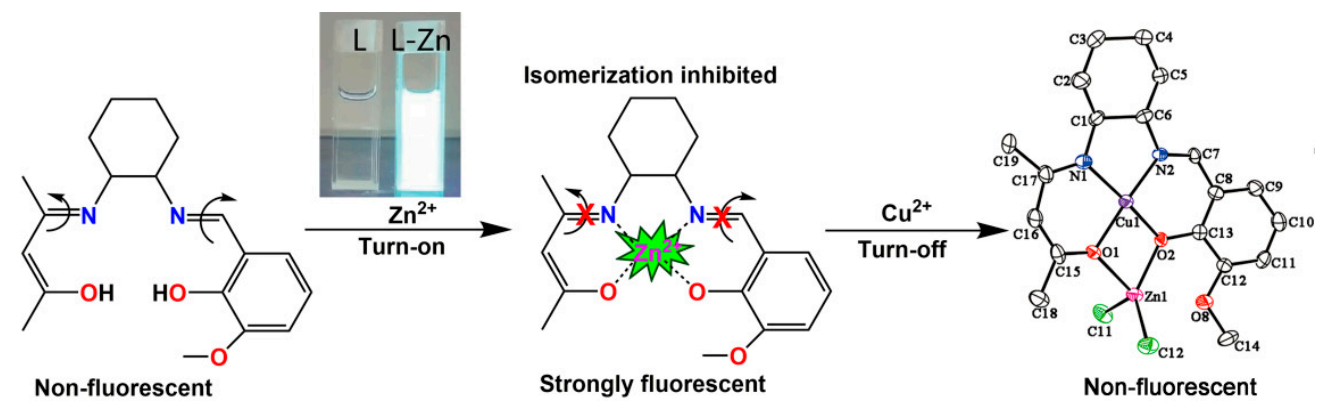

Scheme 2. The proposed receptor-metal chelation mechanism.

\section{Materials and Methods}

\subsection{Reagents and Equipment}

All of the starting materials and solvents were commercially available and used without further purification. Ultrapure water was used throughout the experiments. The solutions of the metal ions were prepared from their chloride salts. The UV-Vis absorption spectra were determined at room temperature on a UV-2600 Milton Ray Spectrofluorometer (Shimadzu, Kyoto, Japan) in a $1 \mathrm{~cm}$ quartz cell. Fluorescence spectroscopy measurements were recorded on a Cary Eclipse Hitachi 4500 spectrophotometer (Hitachi, Tokyo, Japan) (Varian). ${ }^{1} \mathrm{H}-\mathrm{NMR}$ spectra were measured using an Inova-600 Bruker AV 600 spectrometer (Bruker, Karlsruhe, Germany) at room temperature. DMSO- $d_{6}$ was used as a solvent and tetramethylsilane (TMS) as an internal standard. Single crystal X-ray diffraction was conducted on a Bruker Smart Apex II single crystal diffractometer (Bruker, Karlsruhe, Germany). The spectroscopic properties of the probe $\mathbf{L}$ were investigated in an ethanol 
solution at $1 \mathrm{mmol} / \mathrm{L}$ that was diluted to the required concentrations. All the metal ions and anions were initially prepared as a $1 \mathrm{mmol} / \mathrm{L}$ ethanol solution and then diluted to the needed concentrations.

\subsection{Synthesis of the Fluorescent Probe $\mathbf{L}$}

Here, 2,4-pentanedione $(1.00 \mathrm{~g}, 10 \mathrm{mmol})$ in methanol $(15 \mathrm{~mL})$ was added dropwise to a methanol $(20 \mathrm{~mL})$ solution of $(1 R, 2 R)$-diaminocyclohexane $(1.14 \mathrm{~g}, 10 \mathrm{mmol})$. The mixture was heated to reflux for $15 \mathrm{~min}$, and cooled to room temperature. Then, 2-hydroxy3-methoxybenzaldehyde $(1.52 \mathrm{~g}, 10 \mathrm{mmol})$ was added and the solution was stirred for an additional $2 \mathrm{~h}$ at room temperature. It was filtered and the filtrate was left to stand overnight below $0{ }^{\circ} \mathrm{C}$. The resulting yellow precipitate was collected by filtration to give the Schiff-base ligand L ( $2.67 \mathrm{~g}, 84 \%)$. The precipitate was recrystallized from methanol. X-ray quality yellow single crystals of ligand $\mathbf{L}$ were obtained by slow evaporation of a saturated methanol solution. ${ }^{1} \mathrm{H}-\mathrm{NMR}$ (600 MHz, DMSO-TMS): $\delta / \mathrm{ppm} 13.49$ (s, $\left.1 \mathrm{H}, \mathrm{Ar}-\mathrm{OH}\right), 10.74$ $(\mathrm{s}, 1 \mathrm{H},(\mathrm{C}=\mathrm{C}) \mathrm{OH}), 8.39(\mathrm{~s}, 1 \mathrm{H}, \mathrm{CH}=\mathrm{N}), 7.03(\mathrm{~d}, J=7.8 \mathrm{~Hz}, 2 \mathrm{H}, \mathrm{Ar}-\mathrm{H}), 6.94(\mathrm{~d}, J=7.8 \mathrm{~Hz}, 2 \mathrm{H}$, $\mathrm{Ar}-\mathrm{H}), 6.80(\mathrm{t}, J=7.8 \mathrm{~Hz}, 1 \mathrm{H}, \mathrm{Ar}-\mathrm{H}), 4.74(\mathrm{~s}, 1 \mathrm{H}, \mathrm{CH}=\mathrm{C}), 3.77\left(\mathrm{~s}, 3 \mathrm{H}, \mathrm{CH}_{3}-\mathrm{O}\right), 3.61(\mathrm{~m}, 1 \mathrm{H}$, Cy-H-N), $3.10(\mathrm{~m}, 1 \mathrm{H}, \mathrm{Cy}-\mathrm{H}-\mathrm{N}), 1.81\left(\mathrm{~s}, 3 \mathrm{H}, \mathrm{CH}_{3}(\mathrm{C}=\mathrm{N})\right), 1.78\left(\mathrm{~s}, 3 \mathrm{H}, \mathrm{CH}_{3}(\mathrm{C}=\mathrm{C})\right), 1.95-1.37$ (m, 8H, Cy- $\left.\mathrm{CH}_{2}\right) .{ }^{13} \mathrm{C}-\mathrm{NMR}$ (150.9 MHz, DMSO-TMS): $\delta / \mathrm{ppm} 193.2(\mathrm{C}=\mathrm{C}-\mathrm{OH}), 165.6$ $\left(\mathrm{CH}_{3}-\mathrm{C}=\mathrm{N}\right), 162.3(\mathrm{Ar}-\mathrm{C}=\mathrm{N}), 151.0(\mathrm{Ar}-\mathrm{C}-\mathrm{OH}), 148.0\left(\mathrm{Ar}-\mathrm{C}-\mathrm{CH}_{3}\right), 123.2(\mathrm{Ar}-\mathrm{C}-(\mathrm{C}=\mathrm{N}))$, 118.4 (Ar-C), 118.1 (Ar-C), $114.8(\mathrm{Ar}-\mathrm{C}), 94.7(\mathrm{C}=\mathrm{C}-\mathrm{OH}), 72.5(\mathrm{Cy}-\mathrm{C}-\mathrm{N}), 55.9(\mathrm{Cy}-\mathrm{C}-\mathrm{N})$, $55.8\left(\mathrm{CH}_{3}-\mathrm{O}\right), 32.9,32.6,28.6,24.2\left(\mathrm{Cy}-\mathrm{CH}_{2}\right), 23.5\left(\mathrm{CH}_{3}(\mathrm{C}=\mathrm{C})\right), 18.8\left(\mathrm{CH}_{3}(\mathrm{C}=\mathrm{N})\right)$. ESI-MS $m / z$ : calcd. for $\left[\mathrm{C}_{19} \mathrm{H}_{26} \mathrm{~N}_{2} \mathrm{O}_{3}+\mathrm{H}\right]^{+}, 331.2016$; found, 331.2011. Elemental analysis calcd. (\%) for $\mathrm{C}_{19} \mathrm{H}_{26} \mathrm{~N}_{2} \mathrm{O}_{3}$ [330.19 g/mol]: C 68.85, H 8.21, N 8.45. Found (\%): C 68.56, H 8.47, N 8.73.

\subsection{X-ray Crystallography}

Diffraction data for the probe $\mathrm{L}$, Cu-complex, and the $\mathrm{Zn}$-Cu complex were collected on a Bruker SMART APEX II diffractometer at room temperature (298 K) with graphitemonochromated Mo K $\alpha$ radiation $(\lambda=0.71073 \AA$ ). An empirical absorption correction using SADABS was applied for all data [68]. The structures were solved and refined to convergence on F2 for all independent reflections by the full-matrix least squares method using the SHELXL-2014 programs [69] and OLEX2 1.2 [70]. Hydrogen atoms bonded to carbons were included in idealized geometric positions with thermal parameters equivalent to 1.2 times those of the atom to which they were attached. In compound $\mathbf{L}$, one oxygen atom in the solvent water was disordered and there was a large amount of disorder in the structure. In particular, the disordered side-chains are very dynamic and may be considered as a solvent. Short contacts between disordered fragments are to be expected, which caused the observed level B alerts. Crystallographic data and refinement details for L, Cucomplex, and the $\mathrm{Zn}-\mathrm{Cu}$ complex are given in Table S1, Supplementary Materials. CCDC: 2067620, L; 2067621, Cu-complex; and 2067622, Zn-Cu complex contain the supplementary crystallographic data for this paper. These data can be obtained free of charge from the Cambridge Crystallographic Data Centre: www.ccdc.cam.ac.uk/data_request/cif.

\subsection{General Procedure for Analysis}

Before conducting the spectroscopic measurements, the corresponding solutions of probe $\mathbf{L}$ and the metal ions were freshly prepared. For fluorescence spectroscopy selective experiments, test solutions were prepared as follows: a stock solution of probe $\mathbf{L}(1 \mathrm{mM})$ and the reactive species $(1 \mathrm{mM})$ was prepared in ethanol solution and $0.15 \mathrm{~mL}$ of probe $\mathbf{L}$ and $0.15 \mathrm{~mL}$ of the reactive species were placed into a $3 \mathrm{~mL}$ cuvette and then after diluting the solution to $3 \mathrm{~mL}$ with ethanol solution; the final concentration was $50 \mu \mathrm{M}$. The fluorescence spectra were collected at room temperature.

For fluorescence spectroscopy competitive experiments, test solutions were prepared as follows: a stock solution of probe $\mathbf{L}(1 \mathrm{mM})$ and the reactive species $(1 \mathrm{mM})$ was prepared in ethanol solution and $0.15 \mathrm{~mL}$ of probe $\mathrm{L}$ and $0.15 \mathrm{~mL}$ of the reactive species were placed 
into $3 \mathrm{~mL}$ cuvette and mixed. Next, $0.15 \mathrm{~mL}$ of the $\mathrm{Zn}^{2+}$ solution was added to the above mixed solution, which was then diluted to $3 \mathrm{~mL}$ with ethanol. Fluorescence spectra were recorded at room temperature.

For UV-Vis and fluorescence spectroscopy titrations experiments, a stock solution of the probe $\mathbf{L}(1 \mathrm{mM})$ was prepared and $0.15 \mathrm{~mL}$ of the probe $\mathbf{L}$ solution was placed into $3 \mathrm{~mL}$ cuvette. Adding $15-450 \mu \mathrm{L} \mathrm{Zn}^{2+}$ solution to the above cuvette, and then diluting the solution to $3 \mathrm{~mL}$ with different amounts of ethanol solution. UV-Vis and fluorescence spectra were taken at room temperature.

For the Job's plot measurement, the total concentration of the probe $\mathbf{L}$ and $\mathrm{Zn}^{2+}$ was kept at $50 \mu \mathrm{mol}$. $\mathrm{L}$ and the ratio of the concentration of $\mathrm{Zn}^{2+}$ to the concentration of the probe $\mathbf{L}$ was changed to $0: 10,1: 9,2: 8,3: 7,4: 6,5: 5,6: 4,7: 3,8: 2,9: 1$, and 10:0, with the fluorescence intensity at $475 \mathrm{~nm}$ and the ultraviolet absorption intensity at $310 \mathrm{~nm}$ as the vertical axis $\mathrm{Zn}^{2+}$ occupies the probe and the molar ratio of $\mathrm{Zn}^{2+}$ is on the horizontal axis. The spectra of these solutions were immediately recorded by means of the UV-Vis method and fluorescence spectroscopy.

\section{Conclusions}

In summary, a new, low-cost, rapid, and portable Schiff base fluorescent probe L was synthesized and characterized. A "turn-on" fluorescence emission was observed upon sequential addition of $\mathrm{Zn}^{2+}$ and this increases proportionally with increased $\mathrm{Zn}^{2+}$ concentration. Meanwhile, it was found that probe $\mathbf{L}$ has great fluorescence selectivity for $\mathrm{Zn}^{2+}$ over many other important metal ions. Additionally, the method of equivalent molarity of fluorescence and UV spectrum indicated a 1:1 binding mode between $\mathbf{L}$ and $\mathrm{Zn}^{2+}$. Finally, the formation of the $\mathrm{Cu}-\mathrm{Zn}$ complex and the strong quenching behavior of coexisting $\mathrm{Cu}^{2+}$ for $\mathrm{Zn}^{2+}$ may lead to the potential application as an on-off chemosensor candidate for $\mathrm{Cu}^{2+}$.

Supplementary Materials: The following are available online: Figure S1: ${ }^{1} \mathrm{H}-\mathrm{NMR}$ spectrum of $\mathbf{L}$, Figure S2: ${ }^{13}$ C-NMR spectrum of L, Figure S3: HR ESI-MS spectrum of probe L, Figure S4: Absorbance of $\mathbf{L}$ as a function of $\left[\mathrm{Zn}^{2+}\right] /[\mathbf{L}]$, Figure S5: Job's plot of probe $\mathbf{L}$ with $\mathrm{Zn}^{2+}$. Figure S6: ${ }^{1} \mathrm{H}-\mathrm{NMR}$ spectra of probe $\mathbf{L}$ with $0-1$ equiv. of $\mathrm{ZnCl}_{2}$, Table S1: Crystallographic data and refinement details, Table S2: Selected bond lengths and bond angles for complex L, Cu-complex and $\mathrm{Cu}-\mathrm{Zn}$ complex.

Author Contributions: L.-Y.S. and X.-L.C. carried out the experiments; H.X., X.Z., and Y.-L.H. analyzed the experiment data; L.-Y.S. and X.-J.Y. analyzed the X-ray structure; C.R. and Q.-L.Z. wrote the paper. All authors have read and agreed to the published version of the manuscript.

Funding: This work was supported by the National Natural Science Foundation of China (22065009, 22066007), the Guizhou Provincial Natural Science Foundation (grant number [2019] 2792], grant number [2018] 5779-14 and 19NSP035) and Guizhou Medical University Startup Project of Doctor Scientific Research (grant number YJ2020-BK024).

Data Availability Statement: No new data were created or analyzed in this study. Data sharing is not applicable to this article.

Acknowledgments: Carl Redshaw thanks the EPSRC for an Overseas Travel Grant (EP/R023816/1).

Conflicts of Interest: The authors declare no conflict of interest.

Sample Availability: Samples of the compounds L, Cu-complex, and $\mathrm{Zn-Cu}$ complex are available from the authors.

\section{References}

1. Que, E.L.; Domaille, D.W.; Chang, C.J. Metals in neurobiology: Probing their chemistry and biology with molecular imaging. Chem. Rev. 2008, 108, 1517-1549. [PubMed]

2. Hagimori, M.; Mizuyama, N.; Tominaga, Y.; Mukai, T.; Saji, H. A low-molecular-weight fluorescent sensor with $\mathrm{Zn}^{2+}$ dependent bathochromic shift of emission wavelength and its imaging in living cells. Dyes Pigm. 2015, 113, 205-209. [CrossRef]

3. Na, Y.J.; Hwang, I.H.; Jo, H.Y.; Lee, S.A.; Park, G.J.; Kim, C. Fluorescent chemosensor based-on the combination of julolidine and furan for selective detection of zinc ion. Inorg. Chem. Commun. 2013, 35, 342-345. [CrossRef] 
4. Li, X.; Li, J.; Dong, X.; Gao, X.; Zhang, D.; Liu, C. A novel 3-Hydroxychromone fluorescence sensor for intracellular Zn ${ }^{2+}$ and its application in the recognition of prostate cancer cells. Sens. Actuators B Chem. 2017, 245, 129-136. [CrossRef]

5. Falchuk, K.H. The molecular basis for the role of zinc in developmental biology. Mol. Cell. Biochem. 1998, 188, 41-48. [CrossRef]

6. Outten, E.C.; Ohalloran, T.V. Femtomolar sensitivity of metalloregulatory proteins controlling zinc homeostasis. Science 2001, 292, 2488-2492. [CrossRef] [PubMed]

7. Sirangelo, I.; Iannuzzi, C. The role of metal binding in the amyotrophic lateral sclerosis-related aggregation of copper-zinc superoxide dismutase. Molecules 2017, 22, 1429. [CrossRef]

8. Kim, S.K.; Lee, D.H.; Hong, J.I.; Yoon, J. Chemosensors for Pyrophosphate. Acc. Chem. Res. 2009, 42, 23. [CrossRef]

9. Nikura, K.; Anslyn, E.V. Chemosensor ensemble with selectivity for inositol-trisphosphate. J. Am. Chem. Soc. 1998, 120, 8533. [CrossRef]

10. Mathews, C.P.; van Holde, K.E. Biochemistry; Benjamin/Cummings Publishing Company, Inc.: Redwood City, CA, USA, 1990.

11. Guo, Z.; Park, S.; Yoon, J.; Shin, I. Recent progress in the development of near-infrared fluorescent probes for bioimaging applications. Chem. Soc. Rev. 2014, 43, 16-29. [CrossRef]

12. Li, Y.; Zhao, Q.; Yang, H.; Liu, S.-J.; Liu, X.-M.; Zhang, Y.; Hu, T.; Chen, J.; Chang, Z.; Bu, X. A new ditopic ratiometric receptor for detecting zinc and fluoride ions in living cells. Analyst 2013, 138, 5486-5494. [CrossRef]

13. Nyren, P. Enzymatic method for continuous monitoring of DNA polymerase activity. Anal. Biochem. 1987, 167, 235-238. [CrossRef]

14. Ni, X.1.; Zeng, X.; Redshaw, C.; Yamato, T. Ratiometric fluorescent receptors for both $\mathrm{Zn}^{2+}$ and $\mathrm{H}_{2} \mathrm{PO}^{4-}$ ions based on a pyrenyllinked triazole-modified homooxacalix[3]arene: A potential molecular traffic signal with an R-S latch logic circuit. J. Org. Chem. 2011, 76, 5696. [CrossRef] [PubMed]

15. Gupta, V.K.; Mergu, N.; Singh, A.K. Fluorescent chemosensors for $\mathrm{Zn}^{2+}$ ions based on flavonol derivatives. Sens. Actuators $B$ Chem. 2014, 202, 674-682. [CrossRef]

16. Mcquade, L.E.; Lippard, S.J. Cell-trappable quinoline-derivatized fluoresceins for selective and reversible biological Zn(II) detection. Inorg. Chem. 2010, 49, 9535-9545. [CrossRef] [PubMed]

17. Park, S.Y.; Yoon, J.H.; Hong, C.S.; Souane, R.; Kim, J.S.; Matthews, S.E.; Vicens, J. A pyrenyl-appended triazole-based calix[4]arene as a fluorescent sensor for $\mathrm{Cd}^{2+}$ and $\mathrm{Zn}^{2+}$. J. Org. Chem. 2008, 73, 8212-8218. [CrossRef] [PubMed]

18. Tayade, K.; Sahoo, S.K.; Bondhopadhyay, B.; Bhardwaj, V.K.; Singh, N.; Basu, A.; Bendre, R.; Kuwar, A. Highly selective turn-on fluorescent sensor for nanomolar detection of biologically important $\mathrm{Zn}^{2+}$ based on isonicotinohydrazide derivative: Application in cellular imaging. Biosens. Bioelectron. 2014, 61, 429-433. [CrossRef]

19. Gulaboski, R.; Mirceski, V.; Scholz, F. An electrochemical method for determination of the standard Gibbs energy of anion transfer between water and n-octanol. Electrochem. Commun. 2002, 4, 277-283. [CrossRef]

20. Ghaedi, M.; Ahmadi, F.; Shokrollahi, A. Simultaneous preconcentration and determination of copper, nickel, cobalt and lead ions content by flame atomic absorption spectrometry. J. Hazard. Mater. 2007, 142, 272-278. [CrossRef]

21. Khorrami, A.R.; Fakhari, A.R.; Shamsipur, M.; Naeimi, H. Pre-concentration of ultra trace amounts of copper, zinc, cobalt and nickel in environmental water samples using modified C18 extraction disks and determination by inductively coupled plasma-optical emission spectrometry. Int. J. Environ. Anal. Chem. 2009, 89, 319-329. [CrossRef]

22. Wan, J.; Duan, W.; Kai, C.; Tao, Y.; Dang, J.; Zeng, K.; Ge, Y.; Jiang, W.; Dan, L. Selective and sensitive detection of Zn(II) ion using a simple peptide-based sensor. Sens. Actuators 2018, 255, 49-56. [CrossRef]

23. Kim, C.; Kim, B.; Park, K.H.; Kim, K.; Lee, D.; Yang, S.; Joo, N. Effects of short-term chromium supplementation on insulin sensitivity and body composition in overweight children: Randomized, double-blind, placebo-controlled study. J. Nutr. Biochem. 2011, 22, 1030-1034. [CrossRef] [PubMed]

24. Wang, W.; Zhang, Y.; Li, Y.; Zhao, Q. Easily accessible and highly selective "Turn-on" fluorescent sensor for imaging cadmium in living cells. Chem. Res. Chin. Univ. 2013, 29, 632-637. [CrossRef]

25. Zhou, Y.; Jung, J.Y.; Jeon, H.R.; Kim, Y.; Kim, S.-J.; Yoon, J. A novel supermolecular tetrameric vanadate-selective colorimetric and "off-on" sensor with pyrene ligand. Org. Lett. 2011, 13, 2742-2745. [CrossRef]

26. Erdemir, B.S. Tabakci, Selective and sensitive fluorescein-benzothiazole based fluorescent sensor for $\mathrm{Zn}^{2+}$ ion in aqueous media. J. Fluoresc. 2017, 27, 2145-2152. [CrossRef] [PubMed]

27. Tang, X.; Han, J.; Wang, Y.; Bao, X.; Ni, L.; Wang, L.; Li, L. A highly sensitive turn-on fluorescent chemosensor for recognition of $\mathrm{Zn}^{2+}$ and $\mathrm{Hg}^{2+}$ and applications. Spectrochim. Acta A 2017, 184, 177-183. [CrossRef]

28. Santoro, O.; Zhang, X.; Redshaw, C. Synthesis of Biodegradable Polymers: A review on the use of Schiff-base metal complexes as catalysts for the ring opening polymerization (ROP) of cyclic esters. Catalysts 2020, 10, 800. [CrossRef]

29. Epstein, D.M.; Choudhary, S.; Churchill, M.R.; Keil, K.M.; Eliseev, A.V.; Morrow, J.R. Chloroform-soluble Schiff-base Zn(II) or Cd(II) complexes from a dynamic combinatorial library. Inorg. Chem. 2001, 40, 1591-1596. [CrossRef]

30. Raman, N.; Fathima, S.S.A.; Raja, J.D. Designing, synthesis and spectral characterization of Schiff base transition metal complexes: DNA cleavage and antimicrobial activity studies. J. Serb. Chem. Soc. 2008, 73, 1063-1071. [CrossRef]

31. Zhao, Q.; Li, R.F.; Xing, S.K.; Liu, X.M.; Hu, T.L.; Bu, X.H. A highly selective on/off fluorescence sensor for cadmium(II). Inorg. Chem. 2011, 50, 10041-10046. [CrossRef]

32. Aoki, S.; Kagata, D.; Shiro, M.; Takeda, K.; Kimura, E. Metal chelation-controlled twisted intramolecular charge transfer and its application to fluorescent sensing of metal ions and anions. J. Am. Chem. Soc. 2004, 126, 13377-13390. [CrossRef] [PubMed] 
33. Lim, N.C.; Schuster, J.V.; Porto, M.C. Coumarin-based chemosensors for Zinc(II): toward the determination of the design algorithm for CHEF-type and ratiometric probes. Inorg. Chem. 2005, 44, 2018-2030. [CrossRef] [PubMed]

34. Parkesh, R.; Lee, T.C.; Gunnlaugsson, T. Highly selective 4-amino-1,8-naphthalimide based fluorescent photoinduced electron transfer (PET) chemosensors for Zn(ii) under physiological pH conditions. Org. Biomol. Chem. 2007, 5, 310-317. [CrossRef]

35. Dong, Y.; Fan, R.; Chen, W.; Wang, P.; Yang, Y. A simple quinolone Schiff-base containing CHEF based fluorescence 'turn-on' chemosensor for distinguishing $\mathrm{Zn}^{2+}$ and $\mathrm{Hg}^{2+}$ with high sensitivity, selectivity and reversibility. Dalton Trans. 2017, 46, 6769-6775. [CrossRef]

36. Chakraborty, S.; Lohar, S.; Dhara, K.; Ghosh, R.; Dam, S.; Zangrando, E.; Chattopadhyay, P. A new half-condensed Schiff base platform: Structures and sensing of $\mathrm{Zn}^{2+}$ and $\mathrm{H}_{2} \mathrm{PO}^{4-}$ ions in an aqueous medium. Dalton Trans. 2020, 49, 8991-9001. [CrossRef]

37. Dong, W.-K.; Akogun, S.F.; Zhang, Y.; Sun, Y.-X.; Dong, X.-Y. A reversible "turn-on" fluorescent sensor for selective detection of $\mathrm{Zn}^{2+}$. Sens. Actuators B Chem. 2017, 238, 723-734. [CrossRef]

38. Guo, W.T.; Peng, Y.D.; Zhang, Y.; Zhang, H.; Jiang, Y.L. Novel Tridentate Bisoxime Chemosensor for Selective Recognition of Cu ${ }^{2+}$ and $\mathrm{Zn}^{2+}$ with Different Mechanisms. J. Appl. Spectrosc. 2021, 88, 452-460. [CrossRef]

39. Zhu, J.; Zhang, Y.; Chen, Y.; Sun, T.; Tang, Y.; Huang, Y.; Yang, Q.; Ma, D.; Wang, Y.; Wang, M. A Schiff base fluorescence probe for highly selective turn-on recognition of $\mathrm{Zn}^{2+}$. Tetrahedron Lett. 2017, 58, 365-370. [CrossRef]

40. Lopez, J.; Mintz, E.A.; Hsu, F.-L.; Bu, X.R. Novel unsymmetric chiral Schiff bases possessing two different donor moieties: Unique tetradentate ligands from combination of salicylaldehyde and acetylacetone units. Tetrahedron: Asymmetry 1998, 9, 3741-3744. [CrossRef]

41. Chen, X.Q.; Zhou, Y.; Peng, X.J.; Yoon, J.Y. Fluorescent and colorimetric probes for detection of thiols. Chem. Soc. Rev. 2010, 39, 2120. [CrossRef]

42. An, B.K.; Kwon, S.K.; Jung, S.D.; Park, S.Y. Enhanced Emission and Its Switching in Fluorescent Organic Nanoparticles. J. Am. Chem. Soc. 2002, 124, 14410-14415. [CrossRef]

43. Chung, S.K.; Tseng, Y.R.; Chen, C.Y.; Sun, S.S. A Selective Colorimetric $\mathrm{Hg}^{2+}$ Probe Featuring a Styryl Dithiaazacrown Containing Platinum(II) Terpyridine Complex through Modulation of the Relative Strength of ICT and MLCT Transitions. Inorg. Chem. 2011, 50, 2711-2713. [CrossRef]

44. Ashokkumar, P.; Ramakrishnan, V.T.; Ramamurthy, P. Photoinduced Electron Transfer (PET) Based Zn ${ }^{2+}$ Fluorescent Probe: Transformation of Turn-On Sensors into Ratiometric Ones with Dual Emission in Acetonitrile. J. Phys. Chem. A 2011, 115, 14292-14299. [CrossRef]

45. Liu, S.L.; Li, D.; Zhang, Z.; Prakash, G.K.S.; Conti, P.S.; Li, Z.B. Efficient synthesis of fluorescent-PET probes based on [ ${ }^{18}$ F]BODIPY dye. Chem. Commun. 2014, 50, 7371-7373. [CrossRef] [PubMed]

46. Wu, J.S.; Liu, W.M.; Ge, J.C.; Zhang, H.Y.; Wang, P.F. New sensing mechanisms for design of fluorescent chemosensors emerging in recent years. Chem. Soc. Rev. 2011, 40, 3483-3495. [CrossRef] [PubMed]

47. Wen, X.; Wang, Q.; Fan, Z. Highly selective turn-on fluorogenic chemosensor for Zn(II) detection based on aggregation-induced emission. J. Lumin. 2018, 194, 366-373. [CrossRef]

48. Pasha, S.S.; Yadav, H.R.; Choudhury, A.R.; Laskar, I.R. Synthesis of an aggregation-induced emission (AIE) active salicylaldehyde based Schiff base: Study of mechanoluminescence and sensitive Zn(ii) sensing. J. Mater. Chem. C 2017, 5, 9651-9658. [CrossRef]

49. Sun, Y.Q.; Wang, P.; Liu, J.; Zhang, J.Y.; Guo, W. A fluorescent turn-on probe for bisulfite based on hydrogen bond-inhibited $\mathrm{C}$ [double bond, length as m-dash]N isomerization mechanism. Analyst 2012, 137, 3430-3433. [CrossRef]

50. Wang, P.; Liu, J.; Lv, X.; Liu, Y.L.; Zhao, Y.; Guo, W. A Naphthalimide-Based Glyoxal Hydrazone for Selective Fluorescence Turn-On Sensing of Cys and Hcy. Org. Lett. 2012, 14, 520-523. [CrossRef] [PubMed]

51. Jung, H.S.; Ko, K.C.; Lee, J.H.; Kim, S.H.; Bhuniya, S.; Lee, J.Y.; Kim, Y.; Kim, S.J.; Kim, J.S. Rationally Designed Fluorescence Turn-On Sensors: A New Design Strategy Based on Orbital Control. Inorg. Chem. 2010, 49, 8552-8557. [CrossRef]

52. Shiraishi, Y.; Sumiya, S.; Hirai, T. Highly sensitive cyanide anion detection with a coumarin-spiropyran conjugate as a fluorescent receptor. Chem. Commun. 2011, 47, 4953-4955. [CrossRef] [PubMed]

53. Tsui, Y.; Devaraj, S.; Yen, Y.-P. Azo dyes featuring with nitrobenzoxadiazole (NBD) unit: A new selective chromogenic and fluorogenic sensor for cyanide ion. Sens. Actuators B Chem. 2012, 161, 510-519. [CrossRef]

54. Karmakar, M.; Chattopadhyay, S. Synthesis, structure and nitroaromatic sensing ability of a trinuclear zinc complex with a reduced Schiff base ligand: Assessment of the ability of the ligand to sense zinc ion. Polyhedron 2020, 187, 114639. [CrossRef]

55. Das, A.; Jana, S.; Ghosh, A. Modulation of Nuclearity by Zn(II) and Cd(II) in Their Complexes with a Polytopic Mannich Base Ligand: A Turn-On Luminescence Sensor for Zn(II) and Detection of Nitroaromatic Explosives by Zn(II) Complexes. Cryst. Growth Des. 2018, 18, 2335-2348. [CrossRef]

56. Svoboda, I.; Arici, C.; Nazir, H.; Durmus, Z.; Atakol, O.; Fuess, H. \{[ $\mu-N, N^{\prime}$-Bis-(salicyl-idene)-2,2'-di-methyl-1,3-propane-diamine](piperidine)copper(II)\}di-bromo-zinc(II). Acta Cryst. 2001, E57, m584-m586.

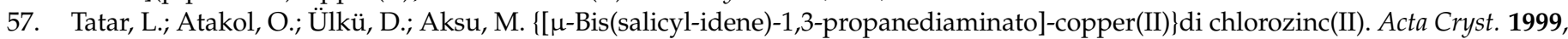
C55, 923-925.

58. Yu, T.Z.; Ding, X.S.; Zhao, Y.L.; Qian, L.; Fan, D.W. Study on the interaction of transition ions with a open-chain crown ether Schiff base. Imaging Sci. Photochem. 2008, 26, 109-115. 
59. You, Z.-L.; Ni, L.-L.; Hou, P.; Zhang, J.-C.; Wang, C. Synthesis, crystal structures, and superoxide dismutase activity of two isostructural copper(II)-zinc(II) complexes derived from $\mathrm{N}, \mathrm{N}^{\prime}$-bis(4-methoxysalicylidene)cyclohexane-1,2-diamine. J. Coord. Chem. 2010, 63, 515-523. [CrossRef]

60. Ülkü, D.; Kaynak, F.B.; Atakol, O.; Aksu, M. Crystal Structure of $\{[\mu$-Bis(salicylidene)-1,3-propanediaminato $]-c o p p e r(I I)\}$ dibromozinc(II). Anal. Sci. 2003, 19, 799-800. [CrossRef]

61. Kim, K.B.; Kim, H.; Song, E.J.; Kim, S.; Noh, I.; Kim, C. A cap-type Schiff base acting as a fluorescence sensor for zinc(ii) and a colorimetric sensor for iron(ii), copper(ii), and zinc(ii) in aqueous media. Dalton Trans. 2013, 42, 16569-16577. [CrossRef]

62. Lee, H.G.; Kim, K.B.; Park, G.J.; Na, Y.J.; Jo, H.Y.; Lee, S.A.; Kim, C. An anthracene-based fluorescent sensor for sequential detection of zinc and copper ions. Inorg. Chem. Commun. 2014, 39, 61-65. [CrossRef]

63. Lee, J.J.; Lee, S.A.; Kim, H.; Nguyen, L.; Noh, I.; Kim, C. A highly selective CHEF-type chemosensor for monitoring Zn ${ }^{2+}$ in aqueous solution and living cells. RSC Adv. 2015, 5, 41905-41913. [CrossRef]

64. Wu, J.; Liu, W.; Zhuang, X.; Wang, F.; Wang, P.; Tao, S.; Zhang, X.; Wu, S.; Lee, S. Fluorescence turn on of coumarin derivatives by metal cations: A new signaling mechanism based on $\mathrm{C}=\mathrm{N}$ isomerization. Org. Lett. 2007, 9, 33-36. [CrossRef] [PubMed]

65. Pan, S.; Tang, H.; Song, Z.; Li, J.; Guo, Y. A novel dual channel fluorescent probe for $\mathrm{Ca}^{2+}$ and $\mathrm{Zn}^{2+}$ based on a coumarin Schiff base. Chin. J. Chem. 2017, 35, 1263-1269. [CrossRef]

66. Ma, Y.; Wang, F.; Kambam, S.; Chen, X. A quinoline-based fluorescent chemosensor for distinguishing cadmium from zinc ions using cysteine as an auxiliary reagent. Sens. Actuators B Chem. 2013, 188, 1116-1122. [CrossRef]

67. Li, H.; Gao, S.; Xi, Z. A colorimetric and "turn-on" fluorescent chemosensor for Zn(II) based on coumarin Shiff-base derivative. Inorg. Chem. Commun. 2009, 12, 300-303. [CrossRef]

68. Sheldrick, G.M. Program SADABS: Area-Detector Absorption Correction; University of Göttingen: Göttingen, Germany, 1996.

69. Sheldrick, G.M. Crystal structure of 8-[7,8-bis-(4-chloro-benzo-yl)-7H-cyclo penta-[a]ace-naphthylen-9-yl]naphthalene-1-carb-oxylic acid. Acta Crystallogr. Sect. C Cryst. Struct. Commun. 2015, 71, 3-8. [CrossRef] [PubMed]

70. Dolomanov, O.V.; Bourhis, L.J.; Gildea, R.J.; Howard, J.A.K.; Puschmann, H. OLEX2: A complete structure solution, refinement and analysis program. J. Appl. Cryst. 2009, 42, 339-341. [CrossRef] 